\title{
Cultural Ecosystem Services of Geodiversity: A Case Study from Stránská skála (Brno, Czech Republic)
}

\author{
Lucie Kubalíková
}

Department of Geology and Pedology, Faculty of Forestry and Wood Technology, Mendel University in Brno, Zemědělská 3, 61300 Brno, Czech Republic; Lucie.Kubalikova@ugn.cas.cz

Received: 12 March 2020; Accepted: 28 March 2020; Published: 31 March 2020

\begin{abstract}
The concept of ecosystem services developed in the second half of the 20th century, and the Millennium Ecosystem Assessment was crucial for its acceptance. This assessment identified the services that ecosystems provide to society, but geodiversity (as an indispensable component of ecosystems) was somewhat underestimated. At present, geodiversity is intensively used by human society and it provides numerous services including cultural as a resource for tourism, recreation, as a part of natural heritage, and to satisfy matters of spiritual importance. The main purpose of this paper is to present the geocultural issues of Stránská skála (a limestone cliff with caves and an anthropogenic underground) in Brno (Czech Republic) and to evaluate the cultural ecosystem services of geodiversity by using the abiotic ecosystem services approach. This assessment of cultural ecosystem services of the Stránská skála enables the identification and description of the functions and services which are provided by geodiversity and confirms the high cultural and geoheritage value of the site.
\end{abstract}

Keywords: abiotic ecosystem services; geocultural site; geoconservation; geoheritage; geotourism

\section{Introduction}

Geodiversity (of an abiotic or inanimate nature) is defined as the natural range (diversity) of geological (rocks, minerals, fossils), geomorphological (landforms, topography, physical processes), soil, and hydrological features including their assemblages, structures, systems, and contribution to landscapes [1,2]. Within this broad concept, geodiversity is a non-evaluative entity that encompasses all the diversity of abiotic nature, regardless of the partial diversity of its individual components [3].

Geodiversity offers multiple functions and services both for nature and for human society [2-6]. It is an essential part of natural ecosystems and it directly or indirectly determines and influences biodiversity [7-15].

The importance of geodiversity for human society is also indisputable: geodiversity is a resource for construction materials or fuels, it provides a platform for numerous human activities, or it contributes to regulating processes as flood control or biochemical control [2,4]. Moreover, geodiversity provides resources or background settings for tourism, sporting activities, and recreation [16-18], and also has numerous cultural functions [19-21].

Despite its undeniable importance, the role of geodiversity is still a bit neglected and is not given as much attention as biodiversity, especially within nature conservation and landscape planning. A complex view of this issue can significantly contribute to the "emancipation" of geodiversity, acceptance of its protection, and its rational use: geodiversity is by no means a competitor of biodiversity, but rather a "basis" for biodiversity [2,8,22-24].

Ecosystem services are the benefits (goods and services) that society obtains from nature [25]. The concept of ecosystem services gradually developed in the second half of the 20th century [26-28], for an overview of the development of the concept, see e.g., [29-31], but the Millennium Ecosystem 
Assessment [25] is considered to be a basic document where the definitions and approaches were presented together with justifications on why the further developing of the concept of ecosystem services was necessary. Today, this concept is fully accepted as an important base for nature conservation, landscape planning, as well as responsible and sustainable use of resources within different types of ecosystems, as proven by numerous papers and monographs [31-33]. The assessment of ecosystem services is considered as a basis for their quantification and environmental accounting [34,35] and references therein, and as an important issue in land-use policy [36,37].

The acceptance of geodiversity within the concept of ecosystem services by a wider community is still ambiguous [38,39]. According to [2,6,40], geodiversity (as an indispensable component of ecosystems) was somewhat underestimated within the Millennium Ecosystem Assessment [25]. These authors point out, for example, the underestimation of non-renewable natural resources, and insufficient consideration of geomorphological processes or insufficient analysis of geodiversity-biodiversity relations.

Based on this, Gray [2,4] Gordon, Barron [6], and Gray et al. [5] define the so-called "abiotic ecosystem services" or "geosystem services" which include regulatory, support, supply, and cultural services. Van Ree and van Beukering [41] as well as Van Ree et al. [42] also emphasize the importance of subsurface and its role in ecosystems. Lele et al. [43] state that it is necessary to include minerals and other abiotic processes in the framework of ecosystem services. Van Der Meulen et al. [44] also propose for abiotic components to be included in the concept of ecosystem services. Ruban et al. [45] discuss the provisioning and cultural ecosystem services of mineral and geoheritage resources and propose to include them into the ecosystem services concept as well. The ecosystem services of water environments (according to [2], water is considered to be a part of geodiversity) were also identified and recognized [46-48]. The ecosystem services of coastal areas, which can be considered as an environment where biotic and abiotic components meet, were also recognized and evaluated [49,50].

The detailed description of ecosystem services provided by geodiversity is elaborated e.g., by Gray [2,4] or Gordon and Barron [6] and they correspond to the classical scheme of ecosystem services [25,51]. To these services, the category of so-called "knowledge services" has also been added [2,38]. Since 2018, abiotic ecosystem services have been included in the Common International Classification of Ecosystem Services (CICES) [51]. Nevertheless, there are still numerous methodological questions regarding the mutual relations between CICES, the concept of natural capital, and geodiversity services as defined by Gray [2,4,38]. Practical applications combining geodiversity research and the concept of abiotic ecosystem services are rather scarce with the exception of water ecosystem services or coastal ecosystem services, as noted previously. To mention some examples: García [52] focuses on the ecosystem services of geodiversity at a coastal area of Brazil and she uses a qualitative approach (identification and description of the ecosystem services of different ecosystems mapped in the study area), Pilogallo et al. [53] apply a GIS-based approach and perform a multiple linear regression analysis for identification of cultural ecosystem services of geosites in southern Italy.

In this paper, an emphasis is placed on the cultural ecosystem services of geodiversity because they are closely related to the issues of geoheritage, geoconservation, and geotourism $[2,4,17,19,21]$. As a study area, Stránská skála in Brno (Czech Republic) was selected. It is a site with specific geocultural issues which is protected and widely used for (geo)tourism, recreation, and environmental education. The cultural and knowledge ecosystem services as defined by Gray [2] were identified there for the purposes of landscape planning and updating the Care plan for this National Natural Monument. It is supposed that this site, where abiotic components play a crucial role, offers numerous cultural services and benefits for society and thus should be considered when developing geotourist activities and managing geoheritage. 


\section{Methods and Theoretical Background}

People have benefited in many ways from cultural ecosystem services, including aesthetic enjoyment, recreation, artistic and spiritual fulfillment, and intellectual development, thus cultural values of ecosystems are as important as other services [25,54].

Generally, cultural ecosystem services can be defined as the nonmaterial benefits people obtain from ecosystems through spiritual enrichment, cognitive development, reflection, recreation, and aesthetic experiences [25]. The conceptual and methodological aspects of cultural ecosystem services were discussed in numerous papers [54-60]. Within cultural ecosystem services, different subcategories can be described (Table 1).

Table 1. Cultural ecosystem services and their subcategories (adapted from $[25,36,55]$ ).

\begin{tabular}{|c|c|}
\hline Values & Examples \\
\hline Recreation and ecotourism & $\begin{array}{l}\text { Landscape features (or sites) used for recreational activities (walking, horse } \\
\text { riding, swimming, gathering wild foods, hiking, sport activities, climbing, etc.) }\end{array}$ \\
\hline Aesthetic values & $\begin{array}{l}\text { Landscape features (or sites) of particular beauty, Aesthetic quality of the } \\
\text { landscape, based on e.g., structural diversity }\end{array}$ \\
\hline Spiritual and religious values & $\begin{array}{c}\text { Landscape features (or sites) of spiritual, religious, or other forms of exceptional } \\
\text { personal meaning }\end{array}$ \\
\hline Educational values & $\begin{array}{c}\text { Landscape features (or sites) that widen knowledge about plant and animal } \\
\text { species or about landscapes and landforms, past climate or } \\
\text { paleogeographical changes }\end{array}$ \\
\hline Cultural heritage values & Landscape features (or sites) relevant to local history and culture \\
\hline Bequest, intrinsic and existence value & $\begin{array}{l}\text { Landscape features (or sites) that have inner values independent on the human } \\
\text { perceptions, specific landscape features as a part of natural heritage }\end{array}$ \\
\hline Inspiration & $\begin{array}{l}\text { Landscape features (or sites) that stimulate new thoughts, ideas, or creative } \\
\text { expressions. Landscape features or species with inspirational value to human arts }\end{array}$ \\
\hline Sense of place & $\begin{array}{l}\text { Landscape features (or sites) that foster a sense of authentic human attachment, } \\
\text { landscape features as a part of local identity }\end{array}$ \\
\hline Knowledge systems & $\begin{array}{l}\text { Importance of the landscape features (or sites) for research activities, e.g., } \\
\text { paleogeographical, paleoclimatical studies, history of research, and knowledge }\end{array}$ \\
\hline Social relations & $\begin{array}{c}\text { Landscape features (or sites) serving as meeting points with friends, e.g., on } \\
\text { special occasions }\end{array}$ \\
\hline Cultural diversity & The diversity of ecosystems that underpin the cultural diversity \\
\hline
\end{tabular}

Cultural ecosystem services have been discussed within various frames, but very limited attention has been paid to geodiversity. There are only a few exceptions where geodiversity is considered within these frameworks, e.g., Bryce et al. [61] who mention geodiversity as being one of the attributes of environmental spaces that are considered as a basis for cultural ecosystem benefits, or de Groot et al. [36] who indicate that a "landscape feature" can be considered as an example of the particular values of cultural ecosystem services (if we consider "landscape features" to be both biotic and abiotic).

However, the importance of cultural and knowledge functions and services of geodiversity was already analyzed by $[2,6,19,20]$ and later supported by numerous examples:

1. geodiversity (mainly landforms) underlines the aesthetic value of landscapes and provides resources for tourism, sports activities, and outdoor recreation [6,16-18], and thus it contributes to sustainable economic development and benefits public health

2. geodiversity elements represent a part of local identity, landforms can be a part of a typical landscape panorama [20,62-64]

3. geodiversity is closely related to religion or spirituality $[19-21,65,66]$

4. geodiversity's valuable part (geoheritage) represents a part of natural heritage $[67,68]$

5. geodiversity possesses numerous knowledge functions and services-from the possibility for the reconstruction of paleogeographical environments and enriching the knowledge of the history of the Earth to the use of geodiversity knowledge in forensic geology [2].

The first step (before the proper description of ecosystem services) involves the identification of ecosystems with important abiotic components. This is based especially on the literature review, 
fieldwork and it takes into account the biotope classification (Care plan) and methodologies for ecosystem services for Czech ambience [69].

For the proper identification of cultural ecosystem services of geodiversity of the study area (Stránská skála in Brno), a slightly modified approach elaborated and presented by Gray [2,4] and Gordon [20] was used (Table 2). Gray [2,4] presented a very complex scheme for geodiversity services following the classical division of ecosystem services to into regulating, supporting, provisioning, and cultural services. A special category of "knowledge" services was added; these services are included in the cultural services in general. Gordon $[19,20]$ also elaborated a scheme for the cultural ecosystem services arising from geodiversity and geoheritage.

Table 2. Abiotic cultural ecosystem services approach adapted from Gray [2] and Gordon [19,20].

\begin{tabular}{|c|c|}
\hline Service & Examples \\
\hline Environmental quality and aesthetic values & local landscape character; therapeutic landscapes for health and well-being \\
\hline Geotourism, recreation, leisure & spectacular mountain views; outdoor recreation; rock climbing; fossil collecting \\
\hline Spiritual and religious meanings & folklore; sacred sites; legends; sense of place \\
\hline Artistic inspiration & literature; music; poetry; painting \\
\hline Other cultural values & archaeological and historical; values relevant to local history and culture \\
\hline Social development & local geological societies; volunteering; field trips \\
\hline Earth history & evolution of life; extinction; origin of landforms; paleoenvironments \\
\hline History of research & early identification of unconformities; fossils; igneous rocks \\
\hline Environmental monitoring and forecasting & baseline studies for climate research; sea-level change; geoforensics \\
\hline Education and employment & sites for field trips and professional training; employment in geoparks \\
\hline Heritage values & a site or landscape feature as a part of natural heritage \\
\hline
\end{tabular}

Abiotic ecosystem services were also included in the CICES as an "extension", however, there is still no consensus on this decision, as it has a lot of pros and cons [25]. There are five abiotic cultural services (or subcategories) defined which try to cover all the variability of services which can be provided by geodiversity (Table 3); nevertheless, some aspects of this classification system are rather problematic and the explication remains rather ambiguous. Moreover, CICES introduced the abiotic ecosystem services as a "supplement" or "extension", so there is a question of whether abiotic ecosystem services are counted as a "full-value" component of the ecosystem services concept within this approach [38].

Table 3. Cultural Abiotic ecosystem services according to CICES Extended (2018).

\begin{tabular}{|c|c|c|}
\hline Division & Group & Class \\
\hline \multirow[t]{2}{*}{$\begin{array}{l}\text { Direct, in-situ, and outdoor interactions } \\
\text { with natural physical systems that depend } \\
\text { on a presence in the environmental setting }\end{array}$} & $\begin{array}{l}\text { Physical and experiential interactions with } \\
\text { natural abiotic components of the environment }\end{array}$ & $\begin{array}{l}\text { Natural, abiotic characteristics of nature } \\
\text { that enable active or passive physical and } \\
\text { experiential interactions }\end{array}$ \\
\hline & Intellectual and representative interactions with & Natural, abiotic characteristics of nature \\
\hline \multirow[t]{2}{*}{$\begin{array}{l}\text { Indirect, remote, often indoor interactions } \\
\text { with physical systems that do not require a } \\
\text { presence in the environmental setting }\end{array}$} & $\begin{array}{c}\text { Spiritual, symbolic, and other interactions with } \\
\text { the abiotic components of the } \\
\text { natural environment }\end{array}$ & $\begin{array}{c}\text { Natural, abiotic characteristics of nature } \\
\text { that enable spiritual, symbolic, and } \\
\text { other interactions }\end{array}$ \\
\hline & $\begin{array}{l}\text { Other abiotic characteristics that have a non-use } \\
\text { value }\end{array}$ & $\begin{array}{c}\text { Natural, abiotic characteristics or features of } \\
\text { nature that have either an existence, option, } \\
\text { or bequest value }\end{array}$ \\
\hline $\begin{array}{l}\text { Other abiotic characteristics of nature that } \\
\text { have cultural significance }\end{array}$ & Other & Other \\
\hline
\end{tabular}

In addition, cultural abiotic services in CICES does not match very well with the already recognized functions, services, and benefits of geodiversity proposed by Gray $[2,4,38]$ or Brilha et al. [39]. The definitions and ambiguous examples are another problem with this approach. That is why the concept proposed by Gray [2,4] was used for the identification of cultural ecosystem services of the presented study area. Until now, any coherent method for quantifying ecosystem services of geodiversity has not been developed and used, while only the qualitative description or assessments are represented by several examples and case studies $[5,6,52]$. That is why the descriptive approach according to $[2,19,20]$ was selected for our case study. 


\section{Study Area}

The elevation of Stránská skála (Figure 1) is situated in Brno city, in the southeastern part of the Czech Republic (South Moravian Region). It covers an area of approximately 16 ha with its highest point at $310 \mathrm{~m}$ a.s.l. Since 1978, the site has been protected (today, according to Act 114/1992 Coll. [70], as a National Natural Monument).

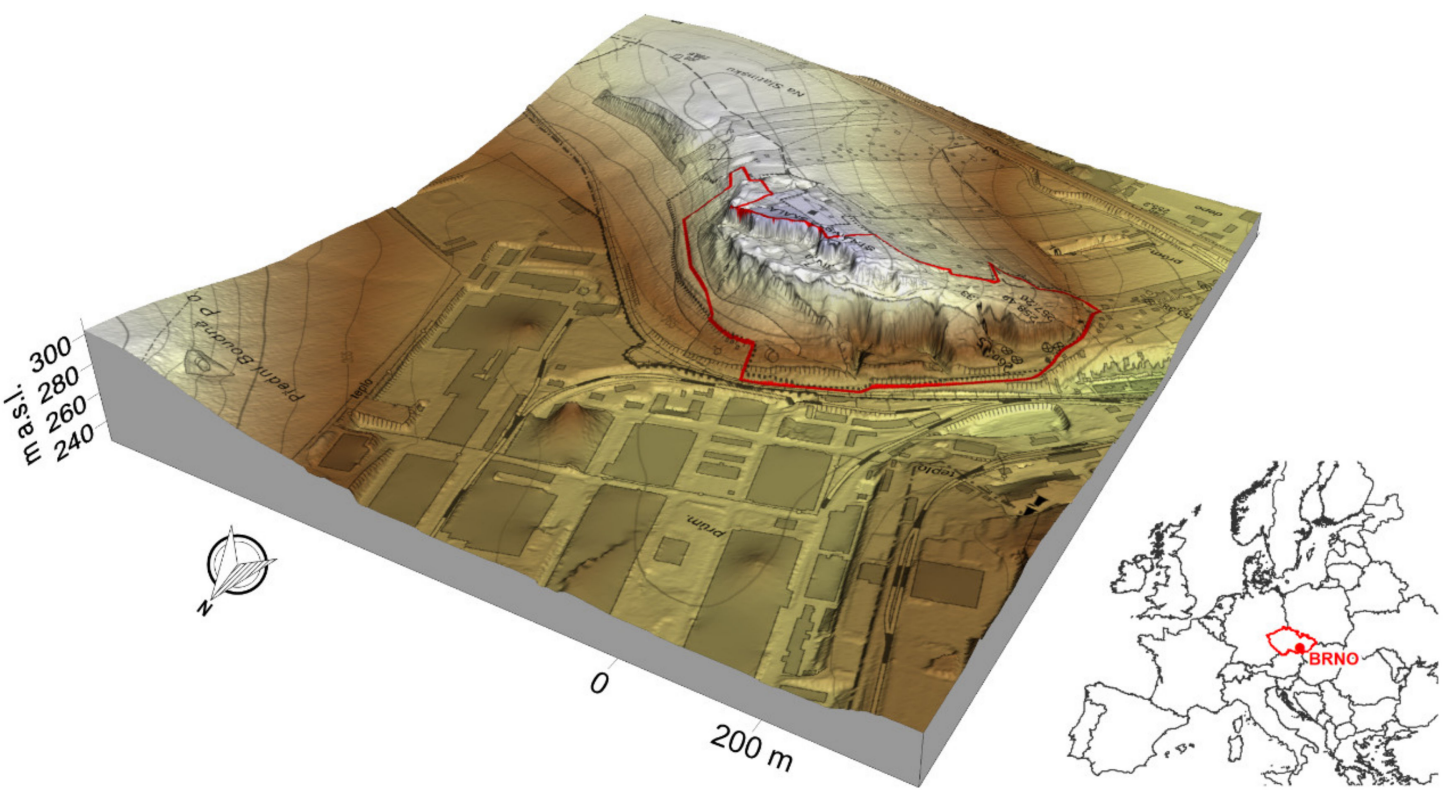

Figure 1. Stránská skála in Brno, Czech Republic: Location of the study area.

The site represents a denudation relic of the Upper Jurassic limestones (Figure 2a) which are paleontologically rich (Figure 2b). According to Gregorová [71], the first paleontological findings were discovered during the 19th Century. In practice, all significant groups of Jurassic marine fauna are included, e.g., crinoids, cephalopods or decapods [71-74]. The talus cone profile (Quaternary sediments) offers fossils from the Pleistocene [75,76]). A sequence of Jurassic rocks (over $50 \mathrm{~m}$ high) was uncovered through quarrying and was traditionally divided into lower chert limestones, crinoid limestones, and upper chert limestones. The limestones are strongly affected by karstification-the relics of three caves have been preserved (Figure 2c). As the site was affected by quarrying since the Middle Ages (see below), it is sometimes difficult to decide which outcrops and depressions are of a natural and anthropogenic origin. It is assumed that depressions were originally natural karst sinkholes that have been modified by surface quarrying.

Two levels of fluvial sediments have been preserved in the abandoned valley of Svitava between Bílá hora and Stránská skála (younger and older gravel cover), which represent complex fluvial strata that are important from a paleogeographical point of view $[72,77,78]$. In close proximity, the Neogene sediments (sands and clays) with rich paleontological findings occur [71].

Concerning anthropogenic transformations, the northwestern slope was considerably changed by quarrying. During WWII, several hundred meters of tunnels for the underground factory Flugmotorenwerke Ostmark and air protection objects were developed $[79,80]$. The site is botanically valuable with the occurrence of xerothermic communities which represent the relics of thermophilic species that have spread from the Mediterranean during the warm Holocene periods. Numerous protected species (e.g., Pulsatilla grandis) can be found here.

Stránská skála was repeatedly inhabited during the Paleolithic period, the oldest settlements at about 600,000 BC [81-84]. It is a site where the evidence of fire use by Homo Erectus was confirmed, so the site can be considered as one of the oldest sites of fire use in Europe [85]. 
About 45,000 years ago, the site was inhabited again, which has been confirmed by findings of the mature chipped stone industry ("bohunicien") that used local material (Figure 3a). The exploitation and use of local material (especially cherts) were confirmed by other findings from the Eneolithic period as well [84,86]. During the Last Glacial Maximum (Epigravettian) (circa 20,000 BP), the site was a settlement of horse hunters [87].
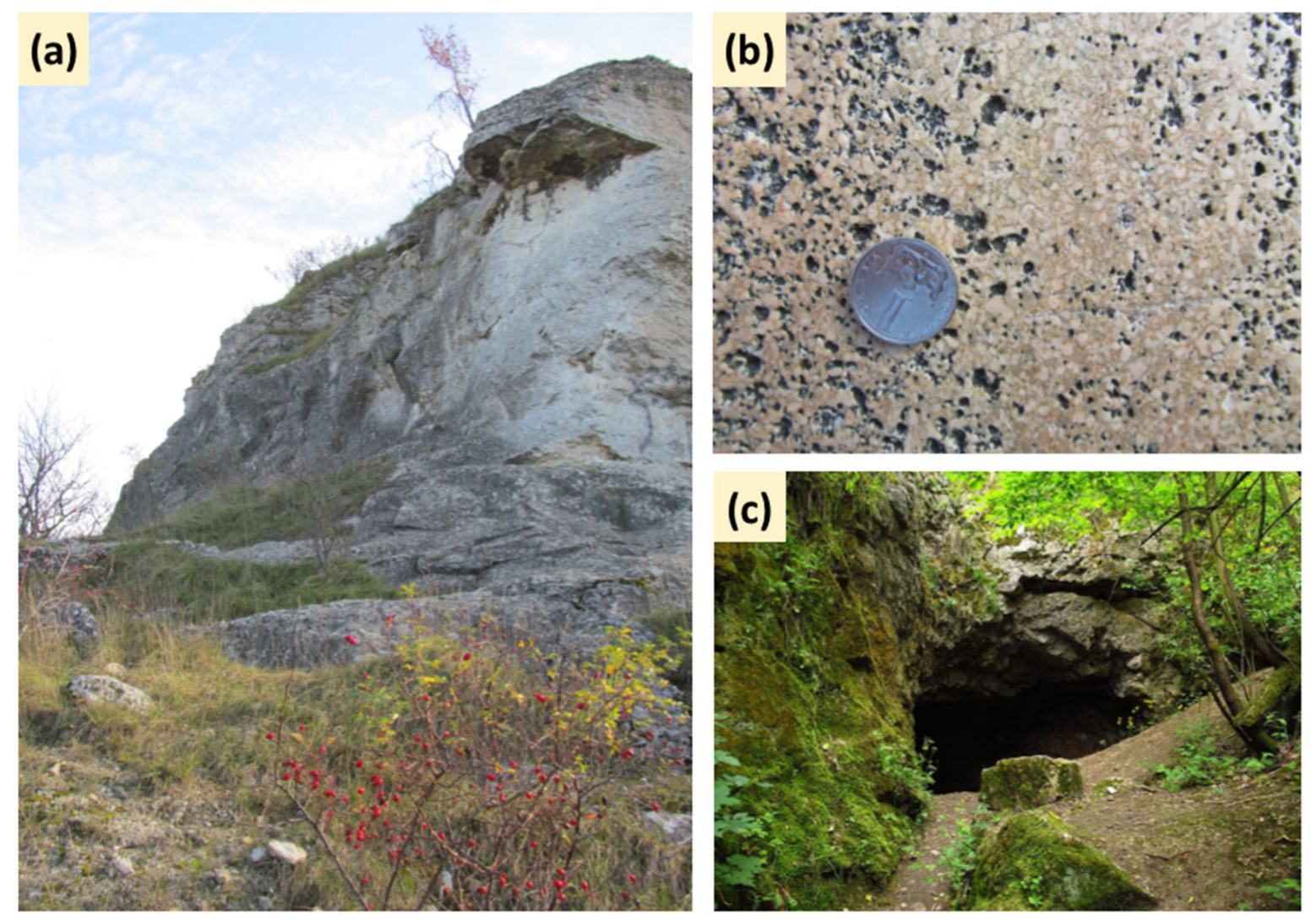

Figure 2. Stránská skála in Brno, Czech Republic: (a) Upper Jurassic limestones displayed in an old quarry; (b) A detail of Crinoidea limestone with debris of Jurassic (Oxfordian) fossils; (c) Underground spaces: most of the caves are modified by human activity. Sources: personal collection.

The importance of Stránská skála for Pleistocene studies was already noted in 1968 [88] and its significance was again confirmed by Musil ed. ([81] and the chapters there), where the research is summarized. Even now, the site is considered to be an exceptional locality for Quaternary geology research $[84,87,89,90]$.

The extraction of building stone probably started at the beginning of the 13th century [91-93]. The material was used for the first time in the Church of St. Jiljí in Brno-Komárov and St. Kunhuta in Brno-Zábrdovice, which was consecrated in the spring of 1211. Thus, the quarry was opened before then. Later, the material was extensively used in numerous monuments and sacral buildings in Brno, e.g., the crypt in Petrov cathedral, the cloisters of the Dominican and Minorite monasteries, Špilberk and Veveři castles, the Old Brno basilica, the Church of St. Thomas and St. James, and the portal of Old Town Hall (Figure 3b). The material was also used in sculptures (Stone Virgin on Orlí Street n. 16, Zderad's Column, statues in Petrov Cathedral, Parnas fountain in Zelný Trh-Figure 3c), and as a tombstone [91]. The limestone was quarried until 1925 and temporarily renewed during 1940-1944 [79]. Nowadays, the deposit of crinoid limestone is not mined anymore and the site is protected as a National Natural Monument [80]. 

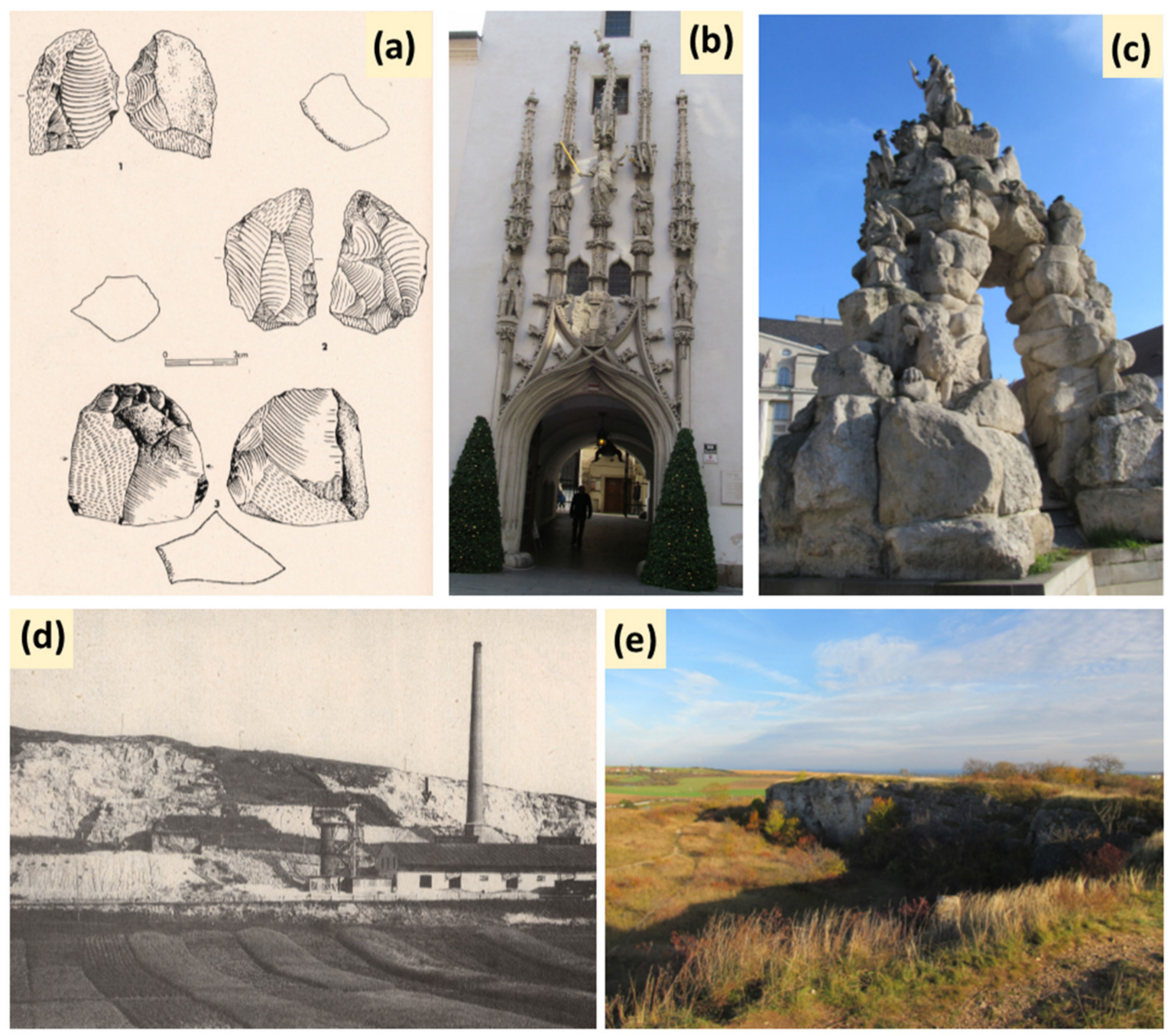

(e)

Figure 3. Geo-cultural issues of Stránská skála: (a) Stone artifacts from the Cromerian age-the testimony of Neolithic settlements; (b) Example of the use of the Crinoidea limestone-portal of the Old Town Hall; (c) Use of limestone on Parnas Fountain at Zelný Trh Market; (d) Stránská skála at the beginning of 20th Century when individual quarries were still in operation; (e) A mosaic of rock outcrops, grasslands and bushes contributes to the aesthetical qualities of the site. Sources: (b,c,e)-personal collection; (a,d)-Musil ed. [81].

Concerning its artistic aspects, Stránská skála has appeared in several drawings and old photographs (Figure 3d). Currently, it is a favorite place for hiking, walking, or climbing and it serves as one of the recreational areas within Brno [80]. Thanks to its visual attractiveness and environmental qualities (a mosaic of rock outcrops, grasslands, bush vegetation and numerous viewpoints), the site can be considered to be aesthetically valuable (Figure 3e).

Stránská skála has inspired several poems e.g., [94] and urban legends that are based on real stories [95]. The underground spaces are considered by a certain group of people as a place where paranormal phenomena occur [96].

\section{Results}

Based on the fieldwork observations, considering the method for ES assessment for Czech conditions [69], the method of García [52] and biotope classification in the Care plan, the main types of ecosystems where the abiotic components play a crucial role were identified: (1) limestone outcrops and quarries (defined within one category; thanks to the long history of quarrying, it is not possible to decide clearly which outcrop is natural and which was modified by quarrying or other human 
activities); (2) underground spaces (be they natural or modified by human activities—caves, adits, remains of industrial spaces); (3) sedimentary areas, especially alluvial fans and talus cones. More details about the geodiversity elements of each ecosystem are presented in Table 4. Abiotic cultural ecosystem services were identified and described based on Gray's scheme [2] for every ecosystem. The results are in Table 5, while specific examples of cultural ecosystem services provided by geodiversity are in Figure 4.

Table 4. Characteristics and elements of geodiversity associated with ecosystems.

\begin{tabular}{|c|c|}
\hline Ecosystem & Description and Elements of Geodiversity \\
\hline \multirow{5}{*}{ Limestone outcrops and quarries } & Jurassic limestone (Oxfordian; Crinoidea limestone, Chert limestones) with fossils \\
\hline & Limestone cliffs that are both natural and modified by quarrying \\
\hline & Depressions (sinkholes) affected by quarrying \\
\hline & Karst microforms (e.g., pavements or scarps) \\
\hline & Less developed soils (rendzinas) \\
\hline \multirow{4}{*}{ Underground spaces } & Caves and accompanying karst features (e.g., speleothems, fissures filled with secondary calcite) \\
\hline & Cave sediments with fossils \\
\hline & Hydrogeological components (the level of underground water) \\
\hline & Alluvial fans, talus cones, river terraces \\
\hline \multirow{3}{*}{ Sedimentary areas } & Neogene sediments (sands and clays of Miocene age - Ottnangian, Badenian with microfossils) \\
\hline & Quaternary sediments (loess, deluviofluvial deposits, fluvial sands) with fossils \\
\hline & Paleosoils, current soils (rendzinas, limited occurrence of luvizems) \\
\hline
\end{tabular}

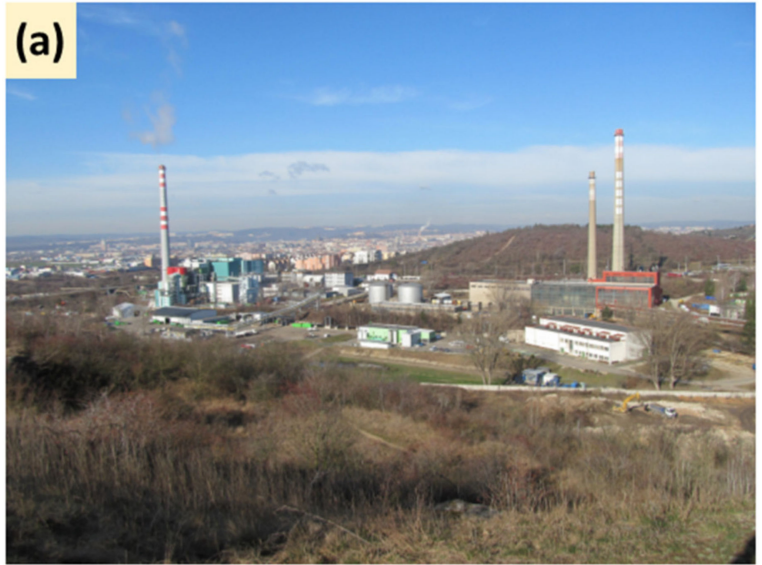

(b)
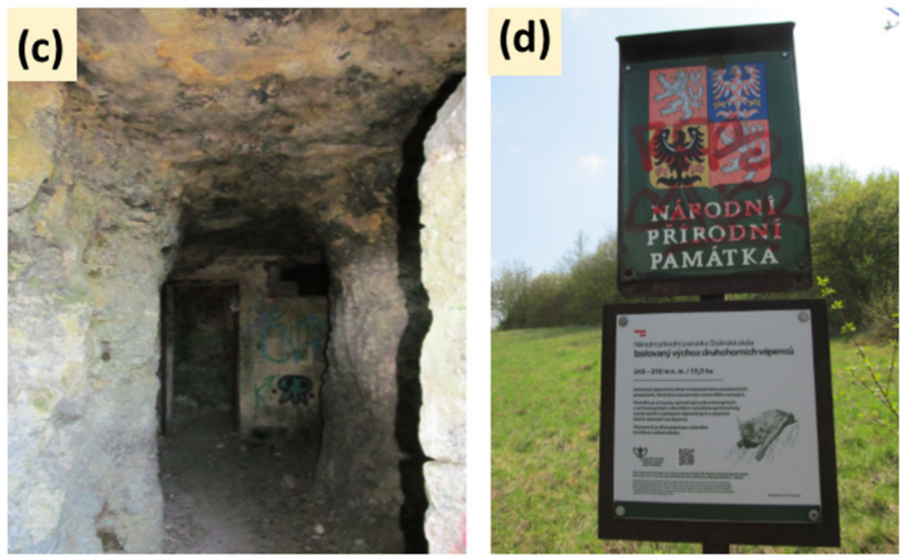

(e)

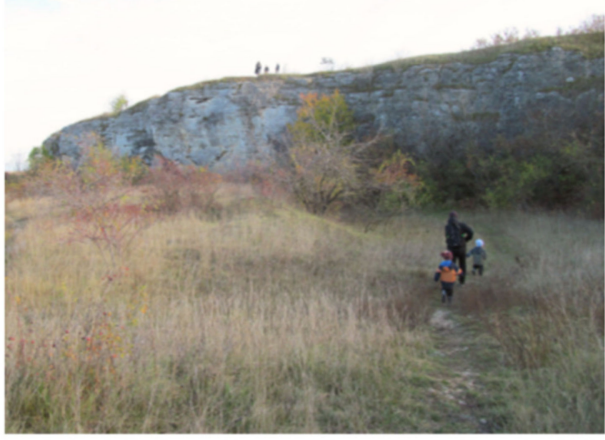

Figure 4. Examples of cultural ecosystem services provided by geodiversity at Stránská skála: (a) Abandoned valley of Svitava River between Stránská skála and Bílá hora Hill is important for palaeogeographical studies; (b) Sinkholes on the plateau allow us to study karst features and the impact of old mining on the landscape; (c) Anthropogenic underground has strong links to the industrial history of the city and it is also a resource for the modern urban legends; (d) Stránská skála is a part of the geoheritage of Southern Moravia, protected as a National Natural Monument; (e) The site is popular for local people and visitors. Source: personal collection. 
Table 5. Identification and description of the ecosystem services

\begin{tabular}{|c|c|c|c|}
\hline Type of Value/Service/Benefit & Limestone Outcrops and Quarries & Underground Spaces & Sedimentary Areas \\
\hline Environmental quality and aesthetic values & $\begin{array}{l}\text { The outcrops contribute to the typical } \\
\text { panorama of Brno city, they increase the } \\
\text { environmental quality of the urban area. From } \\
\text { a certain point of view, the outcrops and } \\
\text { quarry walls can be considered as dramatic } \\
\text { and they are aesthetically valuable thanks to } \\
\text { their configuration. The site forms an } \\
\text { important part of the city's prehistory } \\
\text { and history. }\end{array}$ & $\begin{array}{l}\text { Officially, the underground spaces are not } \\
\text { accessible (except to speleologists and with a } \\
\text { permit), so the assessment of this value was } \\
\text { not possible. The mystic underground partly } \\
\text { contributes to the specific genius loci. }\end{array}$ & $\begin{array}{l}\text { Forestless areas are covered mostly by steppe } \\
\text { and bush vegetation and they complement the } \\
\text { overall pleasant look of the site and they } \\
\text { contribute to the configuration of the space } \\
\text { (the study area is a mosaic of outcrops, } \\
\text { grasslands, bush and forests). The site forms } \\
\text { an important part of the city's prehistory } \\
\text { and history. }\end{array}$ \\
\hline Geotourism, recreation, leisure & $\begin{array}{l}\text { Popular for local people and visitors, climbing, } \\
\text { fossil collecting, and recreation. A viewpoint } \\
\text { of the surroundings. }\end{array}$ & $\begin{array}{l}\text { Practically accessible only for speleologists. } \\
\text { Unofficially explored by people interested in } \\
\text { underground spaces and related phenomena. }\end{array}$ & $\begin{array}{l}\text { Popular for local people and visitors, walking, } \\
\text { recreation. Viewpoint of the surroundings. }\end{array}$ \\
\hline Spiritual and religious meanings & $\begin{array}{l}\text { For local people, it is a site with a strong sense } \\
\text { of place. }\end{array}$ & $\begin{array}{l}\text { The caves (both natural and artificial) are the } \\
\text { subject of several modern legends. }\end{array}$ & $\begin{array}{l}\text { For local people, it is a site with a strong sense } \\
\text { of place. }\end{array}$ \\
\hline Artistic inspiration & $\begin{array}{l}\text { The site with its outcrops was the subject of } \\
\text { several drawings and old photographs. It } \\
\text { appears in several poems. }\end{array}$ & Not found. & $\begin{array}{l}\text { The site with its outcrops was the subject of } \\
\text { several drawings and old photographs. It } \\
\text { appears in several poems. }\end{array}$ \\
\hline Other cultural values & $\begin{array}{l}\text { The stone which was extracted here in the } \\
\text { Middle Ages was used on numerous buildings } \\
\text { in Brno and became the iconic rock of Brno. } \\
\text { Archaeological findings (e.g., flint processing) }\end{array}$ & $\begin{array}{l}\text { The anthropogenic landforms (tunnels of the } \\
\text { underground factory) have strong links to the } \\
\text { industrial history of the city. The use of the } \\
\text { bunker of the civil defence has been important } \\
\text { for military history. }\end{array}$ & $\begin{array}{l}\text { Archeological findings (first evidence of fire } \\
\text { use by Homo Erectus, evidences from } \\
\text { Paleolithic, Neolithic, Eneolithic, traces of } \\
\text { opportunity horse hunting) }\end{array}$ \\
\hline Social development & $\begin{array}{l}\text { The site is a favorite one for non-governmental } \\
\text { organizations (NGOs) that organize } \\
\text { educational programs focused on } \\
\text { nature protection. }\end{array}$ & $\begin{array}{l}\text { Officially not accessible, so the social aspects } \\
\text { cannot be described and assessed. }\end{array}$ & $\begin{array}{l}\text { The site is a favorite one for NGOs that } \\
\text { organize the educational programs focused on } \\
\text { nature protection. }\end{array}$ \\
\hline Earth history & $\begin{array}{c}\text { An important plaeontological site (Jurassic } \\
\text { fossils) for palaeogeographical studies } \\
\text { (paleovalley of Svitava River), the remains of } \\
\text { river terraces. }\end{array}$ & $\begin{array}{l}\text { Analysis of cave sediments, Quaternary } \\
\text { deposits in the caves that consist of bones and } \\
\text { teeth of Quaternary (Pleistocene) animals. }\end{array}$ & $\begin{array}{l}\text { An important site for paleogeographic } \\
\text { reconstructions, fossils (animal bones) in } \\
\text { Quaternary sediments deposited on the slopes } \\
\text { and depressions. }\end{array}$ \\
\hline History of research & $\begin{array}{l}\text { One of the best-explored sites in the Moravian } \\
\text { region, a classical site of Moravian } \\
\text { paleontology, numerous important findings in } \\
\text { the past (e.g., shark teeth) }\end{array}$ & $\begin{array}{l}\text { Contribution to the early findings of Moravian } \\
\text { Paleontology and Quaternary geology, an } \\
\text { important place for exploring cave systems in } \\
\text { Jurassic limestones. }\end{array}$ & $\begin{array}{l}\text { One of the best-explored sites in the Moravian } \\
\text { region, important for Pleistocene studies since } \\
\text { the second half of 20th century. }\end{array}$ \\
\hline Heritage values & \multicolumn{3}{|c|}{$\begin{array}{c}\text { The locality as a whole (including all the ecosystems) is a part of the geoheritage of Southern Moravia. Currently, it is protected as a National } \\
\text { Natural Monument. }\end{array}$} \\
\hline
\end{tabular}


The identification of ecosystem services can then serve as a basis for a SWOT (Strengths, Weaknesses, Opportunities, Threats) analysis of the locality and its geocultural aspects and above all, it may be considered as a source for the Care plan update for this National Natural Monument. Moreover, it can be used as a basis for valuing and quantifying the ecosystem services as well.

\section{Discussion and Conclusions}

The application of a cultural ecosystem services concept on ecosystems where the abiotic component plays a crucial role (e.g., caves, rock outcrops) helps us to identify the importance of the geocultural aspects of the geological and geomorphological localities. Based on the literature review, it was decided to use the abiotic ecosystem services approach as elaborated and presented by Gray [2,4], Gordon [19,20], and Gordon, Barron [6]. For the pilot study, these approaches seemed to be more comprehensive and suitable than the use of the CICES designed by EEA [51], as that offers only several criteria which are not clearly defined. The identification of the cultural ecosystem services of geodiversity by using CICES could be problematic because this classification stems from the assessment of biotic ecosystem services. Some of the categories defined by Gray [2,4], cannot be assigned to the categories of CICES unambiguously, although the categories defined by Gray [2,4], correspond (and most probably are based on) with the classification of ecosystem services presented in MEA 2005 [25] or de Groot et al. [36]. However, in the future, the concept of CICES should be employed as well, as it is officially recognized and can serve a basis for environmental accounting and calculation of ecosystem services values [97].

In general, the inclusion of geodiversity in the identification and assessment of ecosystem services is also vital in terms of understanding and emphasizing its importance. The concept of abiotic ecosystem services needs to be further developed and researchers are encouraged to use it $[38,98]$, as it can help foster a more favorable acceptance of geodiversity in both landscape planning and nature conservation, and because it can contribute to the definition of geodiversity variables [98]. However, it has to be stated that development and the use of clear and unambiguous methods and frames for quantifying abiotic ecosystem services are at the beginning of being outlined [52,98], and their development and use is outside the frame of this paper. The development and application of the assessment and quantification of ecosystem services of geodiversity is one of the possible further directions of this research.

The identification of cultural ecosystem services of the Stránská skála site enabled us to describe the functions and services which are provided by geodiversity, and confirmed a high cultural and geoheritage value of the site. This should be taken into account when updating the Care plan and other strategic documents that deal with nature conservation or sustainable tourism development. The results of this pilot study can be seen as a basis for planning and managing natural resources as well. To a limited extent, these findings can be used as an argument when discussing proposals for educational, tourist, or recreational use of this site. However, to assess the suitability of the site for these purposes, it would be preferable to apply classical methods of geosite and geomorphosite assessment e.g., [99-104]. The proper assessment would be elaborated by experts, but local stakeholders, authorities, or managing organizations would use the results of the assessment for identifying the sites with a geotourist potential $[102,105]$ or designing various geotourist activities such as geopaths or geotourist itineraries [106,107].

The cultural functions of geodiversity are particularly important for their overlaps and mutual relationships with natural and cultural heritage, as evidenced by the example of Stránská skála: on the one hand, the site represents a significant aspect of natural heritage especially thanks to paleontological findings and paleogeographical studies; on the other hand, the site provides a background and settings for recreation, sport, and tourism, it has strong links to various archaeological issues and the built heritage of Brno City, and it is an important site in terms of scientific knowledge and an understanding of environmental history. A comprehensive description of cultural abiotic ecosystem services enables these linkages to be explored and their significance to be highlighted. 
The identification of the cultural ecosystem services of Stránská skála thus confirmed that the cultural ecosystem services of geodiversity can be numerous and should not be neglected when assessing ecosystem services in general. The evaluation of particular geosites and geomorphosites by using the concept of ecosystem services can provide additional arguments to support the sustainable use of geodiversity and finance the management of particular localities.

Funding: The research was supported by Internal Grant Agency MENDELU, project number VP_2019010.

Conflicts of Interest: The author declares no conflict of interest.

\section{References}

1. Gray, M. Geodiversity: Valuing and Conserving Abiotic Nature, 1st ed.; John Wiley: Chichester, UK, 2004; ISBN 978-0-470-09081-7.

2. Gray, M. Geodiversity: Valuing and Conserving Abiotic Nature, 2nd ed.; Wiley-Blackwell: Chichester, UK, 2013; ISBN 978-0-470-74215-0.

3. Zwolinski, Z. Geodiversity. In Encyclopaedia of Geomorphology; Goudie, A.S., Ed.; Routledge: London, UK, 2004; pp. 417-418.

4. Gray, M. Other nature: Geodiversity and geosystem services. Environ. Conserv. 2011, 38, 271-274. [CrossRef]

5. Gray, M.; Gordon, J.E.; Brown, E.J. Geodiversity and the ecosystem approach: The contribution of geoscience in delivering integrated environmental management. Proc. Geol. Assoc. 2013, 124, 659-673. [CrossRef]

6. Gordon, J.E.; Barron, H.F. Valuing Geodiversity and Geoconservation: Developing a More Strategic Ecosystem Approach. Scot. Geogr. J. 2012, 128, 278-297. [CrossRef]

7. Nichols, W.F.; Killingbeck, K.T.; August, P.V. The Influence of Geomorphological Heterogeneity on Biodiversity: II. A Landscape Perspective. Conserv. Biol. 1998, 12, 371-379. [CrossRef]

8. Santucci, V.L. Historical Perspectives on Biodiversity and Geodiversity. George Wright Forum Geodivers. Geoconserv. 2005, 22, 29-34.

9. Jonasson, C.; Gordon, J.E.; Kociánová, M.; Josefsson, M.; Dvořák, I.J.; Thompson, D.B.A. Links between geodiversity and biodiversity in European mountains: Case studies from Sweden, Scotland and the Czech Republic. In Mountains of Northern Europe: Conservation, Management, People and Nature; Thompson, D.B.A., Price, M.F., Galbraith, C.A., Eds.; The Stationery Office: Edinburgh, UK, 2005; pp. 55-70.

10. Jačková, K.; Romportl, D. The Relationship Between Geodiversity and Habitat Richness in Šumava National Park and Křivoklátsko PLA (Czech Republic): A Quantitative Analysis Approach. J. Landsc. Ecol. 2008, 1, 23-38. [CrossRef]

11. Gordon, J.E.; Barron, H.F.; Hansom, J.D.; Thomas, M.F. Engaging with geodiversity-Why it matters. Proc. Geol. Assoc. 2012, 123, 1-6. [CrossRef]

12. Hjort, J.; Gordon, J.E.; Gray, M.; Hunter, M.L. Why geodiversity matters in valuing nature's stage. Conserv. Biol. 2015, 29, 630-639. [CrossRef] [PubMed]

13. Tukiainen, H.; Alahuhta, J.; Field, R.; Ala-Hulkko, T.; Lampinen, R.; Hjort, J. Spatial relationship between biodiversity and geodiversity across a gradient of land-use intensity in high-latitude landscapes. Landsc. Ecol. 2017, 32, 1049-1063. [CrossRef]

14. Tukiainen, H.; Kiuttu, M.; Kalliola, R.; Alahuhta, J.; Hjort, J. Landforms contribute to plant biodiversity at alpha, beta and gamma levels. J. Biogeogr. 2019, 46, 1699-1710. [CrossRef]

15. Alahuhta, J.; Ala-Hulkko, T.; Tukiainen, H.; Purola, L.; Akujärvi, A.; Lampinen, R.; Hjort, J. The role of geodiversity in providing ecosystem services at broad scales. Ecol. Indic. 2018, 91, 47-56. [CrossRef]

16. Reynard, E.; Holzmann, C.; Guex, D. Géomorphologie et tourisme: Quelles relations? In Proceedings of the Géomorphologie et tourisme, Actes de la Réunion annuelle de la Société Suisse de Géomorphologie (SSGm), Finhaut, Switzerland, 21-23 Septembrer 2001; Reynard, E., Holzmann, C., Guex, D., Summermatter, N., Eds.; Institut de Géographie: Lausanne, Switzerland, 2003; Volume 24, pp. 1-10.

17. Dowling, R.; Newsome, D. Geotourism: The Tourism of Geology and Landscape; Goodfellow Publishers Ltd.: Woodeaten, UK, 2010; ISBN 978-1-906884-09-3.

18. Dowling, R.K.; Newsome, D. Handbook of Geotourism; Edward Elgar Publishing: Cheltenham, UK, 2018; ISBN 978-1-78536-885-1. 
19. Gordon, J.E. Rediscovering a Sense of Wonder: Geoheritage, Geotourism and Cultural Landscape Experiences. Geoheritage 2012, 4, 65-77. [CrossRef]

20. Gordon, J.E. Geoheritage, Geotourism and the Cultural Landscape: Enhancing the Visitor Experience and Promoting Geoconservation. Geosciences 2018, 8, 136. [CrossRef]

21. Reynard, E.; Giusti, C. The Landscape and the Cultural Value of Geoheritage. In Geoheritatge: Assessment, Protection and Management; Brilha, J., Reynard, E., Eds.; Elsevier: Amsterdam, The Netherlands, 2018; pp. 147-166. ISBN 978-0-12-809531-7.

22. Cílek, V. Geodiverzita-Geologická rozmanitost Čech. Vesmír 2000, 2, 95-97.

23. Cílek, V. Geodiverzita-Opomíjený aspekt ochrany přírody a krajiny (Geodiversity-Neglected aspect of landscape and nature conservation). Zprávy o geologických výzkumech v roce 2001, 35, 13-15.

24. Ložek, V. Biodiverzita, ekofenomény a geodiverzita. Vesmír 2000, 2, 97-98.

25. Reid, W.; Mooney, H.; Cropper, A.; Capistrano, D.; Carpenter, S.; Chopra, K. Millennium Ecosystem Assessment. Ecosystems and Human Well-Being: Synthesis; Island Press: Washington, DC, USA, 2005.

26. Costanza, R.; d'Arge, R.; de Groot, R.; Farber, S.; Grasso, M.; Hannon, B.; Limburg, K.; Naeem, S.; O'Neill, R.V.; Paruelo, J.; et al. The value of the world's ecosystem services and natural capital. Nature 1997, 387, 253-260. [CrossRef]

27. Daily, G.C. Nature's services. Societal Dependence on Natural Ecosystems; Island Press: Washington, DC, USA, 1997; ISBN 1-55963-475-8.

28. Odum, H.T.; Odum, E.P. The Energetic Basis for Valuation of Ecosystem Services. Ecosystems 2000, 3, $21-23$. [CrossRef]

29. Liu, S.; Costanza, R.; Farber, S.; Troy, A. Valuing Ecosystem Services: Theory, Practice, and the Need for a Transdisciplinary Synthesis. Ann. N. Y. Acad. Sci. 2010, 1185, 54-78. [CrossRef]

30. Braat, L.C.; de Groot, R. The ecosystem services agenda:bridging the worlds of natural science and economics, conservation and development, and public and private policy. Ecosyst. Serv. 2012, 1, 4-15. [CrossRef]

31. Costanza, R.; de Groot, R.; Braat, L.; Kubiszewski, I.; Fioramonti, L.; Sutton, P.; Farber, S.; Grasso, M. Twenty years of ecosystem services: How far have we come and how far do we still need to go? Ecosyst. Serv. 2017, 28, 1-16. [CrossRef]

32. Burkhard, B.; Maes, J. Mapping Ecosystem Services; Pensoft Publishers: Sofia, Bulgaria, 2017; ISBN 978-954-642-830-1.

33. Jacobs, S.; Dendoncker, N.; Keune, H. (Eds.) Ecosystem Services: Global Issues, Local Practices; Elsevier: Amsterdam, The Netherlands, 2014; ISBN 978-0-12-419964-4.

34. TEEB. Mainstreaming the Economics of Nature: A Synthesis of the Approach, Conclusions and Recommendations of TEEB; Progress Press: Mriehel, Malta, 2010; ISBN 978-3-9813410-3-4.

35. Boerema, A.; Rebelo, A.J.; Bodi, M.B.; Esler, K.J.; Meire, P. Are ecosystem services adequately quantified? J. Appl. Ecol. 2017, 54, 358-370. [CrossRef]

36. De Groot, R.S.; Alkemade, R.; Braat, L.; Hein, L.; Willemen, L. Challenges in integrating the concept of ecosystem services and values in landscape planning, management and decision making. Ecol. Complex. 2010, 7, 260-272. [CrossRef]

37. Bouwma, I.; Schleyer, C.; Primmer, E.; Winkler, K.J.; Berry, P.; Young, J.; Carmen, E.; Špulerová, J.; Bezák, P.; Preda, E.; et al. Adoption of the ecosystem services concept in EU policies. Ecosyst. Serv. 2018, 29, $213-222$. [CrossRef]

38. Gray, M. The confused position of the geosciences within the "natural capital" and "ecosystem services" approaches. Ecosyst. Serv. 2018, 34, 106-112. [CrossRef]

39. Brilha, J.; Gray, M.; Pereira, D.I.; Pereira, P. Geodiversity: An integrative review as a contribution to the sustainable management of the whole of nature. Environ. Sci. Policy 2018, 86, 19-28. [CrossRef]

40. Brouwer, R.; Brander, L.; Kuik, O.; Papyrakis, E.; Bateman, I. A Synthesis of Approaches to Assess and Value Ecosystem Services in the EU in the Context of TEEB; Institute for Environmental Studies, VU University Amsterdam: Amsterdam, The Netherlands, 2013; Available online: https:/www.cbd.int/financial/values/euvaluation2013.pdf (accessed on 27 February 2020).

41. Van Ree, C.C.D.F.; van Beukering, P.J.H. Geosystem services: A concept in support of sustainable development of the subsurface. Ecosyst. Serv. 2016, 20, 30-36. [CrossRef]

42. Van Ree, C.C.D.F.; Van Beukering, P.J.H.; Boekestijn, J. Geosystem services: A hidden link in ecosystem management. Ecosyst. Serv. 2017, 26, 58-69. [CrossRef] 
43. Lele, S.; Springate-Baginski, O.; Lakerveld, R.; Deb, D.; Dash, P. Ecosystem Services: Origins, Contributions, Pitfalls, and Alternatives. Conserv. Soc. 2013, 11, 343. [CrossRef]

44. Van der Meulen, E.S.; Braat, L.C.; Brils, J.M. Abiotic flows should be inherent part of ecosystem services classification. Ecosyst. Serv. 2016, 19, 1-5. [CrossRef]

45. Ruban, D.A.; Tiess, G.; Sallam, E.S.; Ponedelnik, A.A.; Yashalova, N.N. Combined mineral and geoheritage resources related to kaolin, phosphate, and cement production in Egypt: Conceptualization, assessment, and policy implications. Sustain. Environ. Res. 2018, 28, 454-461. [CrossRef]

46. Martin-Ortega, J.; Ferrier, R.C.; Gordon, I.J.; Khan, S. (Eds.) Water Ecosystem Services. A Global Perspective; Cambridge University Press: Cambridge, UK, 2015; ISBN 9781316178904.

47. Grizzetti, B.; Lanzanova, D.; Liquete, C.; Reynaud, A.; Cardoso, A.C. Assessing water ecosystem services for water resource management. Environ. Sci. Policy 2016, 61, 194-203. [CrossRef]

48. Hackbart, V.C.S.; de Lima, G.T.N.P.; dos Santos, R.F. Theory and practice of water ecosystem services valuation: Where are we going? Ecosyst. Serv. 2017, 218-227. [CrossRef]

49. Elliff, C.I.; Kikuchi, R.K.P. The ecosystem service approach and its application as a tool for integrated coastal management. Nat. Conservacao 2015, 2, 105-111. [CrossRef]

50. Sousa, L.P.; Sousa, A.I.; Alves, F.L.; Lillebø, A.I. Ecosystem services provided by a complex coastal region: Challenges of classification and mapping. Sci. Rep. UK 2016, 6, 1-14. [CrossRef] [PubMed]

51. Common International Classification of Ecosystem Services V5.1 2018. Available online: https://cices.eu/ (accessed on 12 February 2020).

52. Garcia, M.d.G.M. Ecosystem Services Provided by Geodiversity: Preliminary Assessment and Perspectives for the Sustainable Use of Natural Resources in the Coastal Region of the State of São Paulo, Southeastern Brazil. Geoheritage 2019, 11, 1257-1266. [CrossRef]

53. Pilogallo, A.; Nolè, G.; Amato, F.; Saganeiti, L.; Bentivenga, M.; Palladino, G.; Scorza, F.; Murgante, B.; Casas, G.L. Geotourism as a Specialization in the Territorial Context of the Basilicata Region (Southern Italy). Geoheritage 2019, 11, 1435-1445. [CrossRef]

54. Daniel, T.C.; Muhar, A.; Arnberger, A.; Aznar, O.; Boyd, J.W.; Chan, K.M.A.; Costanza, R.; Elmqvist, T.; Flint, C.G.; Gobster, P.H.; et al. Contributions of cultural services to the ecosystem services agenda. Proc. Natl. Acad. Sci. USA 2012, 109, 8812-8819. [CrossRef]

55. Milcu, A.; Hanspach, J.; Abson, D.; Fischer, J. Cultural Ecosystem Services: A Literature Review and Prospects for Future Research. Ecol. Soc. 2013, 18(3), 44. [CrossRef]

56. Hernández-Morcillo, M.; Plieninger, T.; Bieling, C. An empirical review of cultural ecosystem service indicators. Ecol. Indic. 2013, 29, 434-444. [CrossRef]

57. Cooper, N.; Brady, E.; Steen, H.; Bryce, R. Aesthetic and spiritual values of ecosystems: Recognising the ontological and axiological plurality of cultural ecosystem 'services'. Ecosyst. Serv. 2016, 21, 218-229. [CrossRef]

58. Fish, R.; Church, A.; Winter, M. Conceptualising cultural ecosystem services: A novel framework for research and critical engagement. Ecosyst. Serv. 2016, 21, 208-217. [CrossRef]

59. Small, N.; Munday, M.; Durance, I. The challenge of valuing ecosystem services that have no material benefits. Glob. Environ. Chang. 2017, 44, 57-67. [CrossRef]

60. Stålhammar, S.; Pedersen, E. Recreational cultural ecosystem services: How do people describe the value? Ecosyst. Serv. 2017, 26, 1-9. [CrossRef]

61. Bryce, R.; Irvine, K.N.; Church, A.; Fish, R.; Ranger, S.; Kenter, J.O. Subjective well-being indicators for large-scale assessment of cultural ecosystem services. Ecosyst. Serv. 2016, 21, 258-269. [CrossRef]

62. Górska-Zabielska, M.; Zabielski, R. Geotourism Development in an Urban Area based on the Local Geological Heritage (Pruszków, Central Mazovia, Poland). In Urban Geomorphology: Landforms and Processes in Cities; Thornbush, M., Casey, A., Eds.; Elsevier: Amsterdam, The Netherlands, 2018; pp. 37-54. ISBN 978-0-12-811951-8.

63. Reynard, E.; Pica, A.; Coratza, P. Urban Geomorphological Heritage. An Overview. Quaestiones Geographicae 2017, 36, 7-20. [CrossRef]

64. Da Silva, C.M. Geodiversity and Sense of Place: Local Identity Geological Elements in Portuguese Municipal Heraldry. Geoheritage 2019, 11, 949-960. [CrossRef]

65. Vitaliano, D.B. Geomythology: The Impact of Geologic Events on History and Legend with Special Reference to Atlantis. J. Folk. Inst. 1968, 5, 5-30. [CrossRef] 
66. Piccardi, L.; Masse, W.B. (Eds.) Myth and Geology; Special Publications No. 273; Geological Society: London, UK, 2007; ISBN 9781862395213.

67. Dingwall, P.; Weighell, T.; Badman, T. Geological World Heritage: A global framework: A contribution to the global theme study of World Heritage Natural Sites. IUCN: Gland, Switzerland, 2005; Available online: https://portals.iucn.org/library/sites/library/files/documents/Rep-2005-009.pdf (accessed on 27 February 2020).

68. Reynard, E.; Brilha, J. Geoheritage: Assessment, Protection, and Management, 1st ed.; Elsevier: Amsterdam, The Netherlands; Cambridge, MA, USA, 2017; ISBN 978-0-12-809542-3.

69. Vačkář, D.; Frélichová, J.; Lorencová, E.; Pártl, A.; Loučková, B. Metodologický Rámec Integrovaného Hodnocení EkosystéMových Služeb v České Republice. Ministry of the Environment of the Czech Republic: Prague, Czech Republic, 2014. Available online: www.ecosystemservices.cz/userfiles/page/ 246/72fc39cc8d8e7f501934794636059d8c.pdf (accessed on 27 February 2020).

70. Government of the Czech Republic. Law 114/1992 Coll. on Nature Conservation and Landscape Protection; Government of the Czech Republic: Prague, Czech Republic, 1992. Available online: https://www. zakonyprolidi.cz/cs/1992-114 (accessed on 22 August 2019).

71. Gregorová, R. Zkameněliny na Stránské skále. In Stránská Skála: Výjimečná Lokalita; Moravské zemské muzeum: Brno, Czech Republic, 2001; pp. 6-8.

72. Müller, P.; Novák, Z. Geologie Brna a Okolí Český geologický ústav: Prague, Czech Republic, 2000; ISBN 80-7075-416-8.

73. Hyžný, M.; Starzyk, N.; Robins, C.M.; Kočová Veselská, M. Taxonomy and palaeoecology of a decapod crustacean assemblage from the Oxfordian of Stránská skála (Southern Moravia, Czech Republic). Bull. Geosci. 2015, 90, 633-650. [CrossRef]

74. Stránská skála. Available online: http://lokality.geology.cz/784 (accessed on 10 March 2020).

75. Ivanov, M. Pleistocene reptiles at the locality of the Stránská Skála Hill. In Stránská skála Hill. Excavation of Open-Air Sediments 1964-1972; Moravské Zemské Muzeum: Brno, Czech Republic, 1995; pp. 93-109.

76. Kovanda, J. Palaeomalacoanalysis of the lower part of the talus cone profile at the Stránská Skála Hill near Brno. In Stránská skála Hill. Excavation of Open-Air Sediments 1964-1972; Moravské zemské muzeum: Brno, Czech Republic, 1995; pp. 137-144.

77. Karásek, J. Stránská terrace and its relation to talus deposits on the Stránská skála Hill. In Stránská skála Hill. Excavation of Open-Air Sediments 1964-1972; Moravské zemské muzeum: Brno, Czech Republic, 1995; pp. $29-42$.

78. Nehyba, S. Contribution to the knowledge of some coarse clastics in the area of the Stránská Skála Hill. In Stránská skála Hill. Excavation of Open-Air Sediments 1964-1972; Moravské zemské muzeum: Brno, Czech Republic, 1995; pp. 43-46.

79. Polák, A. Soupis lomů ČSR, Číslo 50, List Brno (4357); Nakladatelství Československé Akademie věd: Prague, Czech Republic, 1956.

80. Plán péče o Národní přírodní památku Stránská skála na období 2013-2020 (Care plan on the Stránská skála National Natural Monument 2013-2020). Available online: https://rusop.nature.cz/ost/chrobjekty/zchru/ index.php?SHOW_ONE=1andID=700 (accessed on 10 March 2020).

81. Musil, R. The Stránská Skála Hill-Its importance and significance. In Stránská skála Hill. Excavation of Open-Air Sediments 1964-1972; Moravské zemské Muzeum: Brno, Czech Republic, 1995; pp. 177-208. ISBN 80-7028-070-0.

82. Valoch, K. Early Human activities at the Stránská skála Hill. In Stránská skála Hill. Excavation of Open-Air Sediments 1964-1972; Moravské zemské muzeum: Brno, Czech Republic, 1995; pp. 159-168.

83. Svoboda, J.; Bar-Yosef, O. Stránská Skála. Origins of the Upper Paleolithic in the Brno Basin, Moravia, Czech Republic; Peabody Museum of Archaeology and Ethnology, Harvard University: Cambridge, MA, USA, 2003; Volume D, ISBN 978-0-87365-551-4.

84. Bartík, J.; Škrdla, P.; Šebela, L.; Přichystal, A.; Nejman, L. Mining and processing of the Stránská skála-type chert during the Late Neolithic and Early Eneolithic periods. Archeologické Rozhledy 2019, 71, 373-417.

85. Přichystal, A.; Strnad, M. The evidence of fire use by the hominids of the species Homo erectus at the Stránská Skála Hill in Brno. In Stránská skála Hill. Excavation of Open-Air Sediments 1964-1972; Moravské zemské Muzeum: Brno, Czech Republic, 1995; pp. 149-152. 
86. Škrdla, P.; Plch, M. Osídlení epigravettienu v okolí Stránské skály (okr. Brno-město). Archeologické Rozhledy Praha 1993, 45, 429-435.

87. Boriová, S.; Sázelová, S.; Novák, M.; Štelcl, J.; Svoboda, J. Human and non-human taphonomic effects on faunal remains from the Late Upper Paleolithic: A case study from the Stránská skála IV site, Czech Republic. Int. J. Osteoarchaeol. 2019, 1-15. [CrossRef]

88. Musil, R. Stranska Skala: Its Meaning for Pleistocene Studies. Curr. Anthropol. 1968, 9, 534-539. [CrossRef]

89. Nejman, L.; Rhodes, E.; Škrdla, P.; Tostevin, G.; Neruda, P.; Nerudová, Z.; Valoch, K.; Oliva, M.; Kaminská, L.; Svoboda, J.A.; et al. New Chronological Evidence for the Middle to Upper Palaeolithic Transition in the Czech Republic and Slovakia: New Optically Stimulated Luminescence Dating Results. Archaeometry 2011, 53, 1044-1066. [CrossRef]

90. Szymanek, M.; Julien, M.-A. Early and Middle Pleistocene climate-environment conditions in Central Europe and the hominin settlement record. Quaternary Sci. Rev. 2018, 198, 56-75. [CrossRef]

91. Mrázek, I. Kamenná tvár̆ Brna; Moravské zemské Muzeum: Brno, Czech Republic, 1993; ISBN 80-7028-048-4.

92. Dvořák, J. Stavební kámen starší středověké architektury v Brně. In Z pravěku do středověku; Michna, P., Nekuda, R., Unger, J., Eds.; Muzejní a vlastivědná soilečnost: Brno, Czech Republic, 1997; pp. 165-174.

93. Hálová-Jahodová, C. Brno, dílo př́rody, člověka a dějin; Blok: Brno, Czech Republic, 1971.

94. Blažek, K.; Grmolec, Z.; Kalabisová, J.; Kopčilová, E.; Kořenek, J.; Kvasnice, J.; Němec, L.; Schildberger, F.; Svoboda, L. Hníza stěhovavých ptáků: Sbornik básní mladých jihomor. autoru; Blok: Brno, Czech Republic, 1978.

95. Encyklopedie Dějin Města Brna: Tragická Nehoda na Stránské Skále. Available online: https://www. encyklopedie.brna.cz/home-mmb/?acc=profil_udalostiandload=3511 (accessed on 10 March 2020).

96. Agartha.cz: Stránská Skála—jevy ve Štolách Potvrzeny! Available online: http://agartha.cz/html/pruzkumy/ brno/stranska/index.php (accessed on 11 March 2020).

97. Frélichová, J.; Vačkář, D.; Pártl, A.; Loučková, B.; Harmáčková, Z.V.; Lorencová, E. Integrated assessment of ecosystem services in the Czech Republic. Ecosyst. Serv. 2014, 8, 110-117. [CrossRef]

98. Schrodt, F.; Bailey, J.J.; Kissling, W.D.; Rijsdijk, K.F.; Seijmonsbergen, A.C.; van Ree, D.; Hjort, J.; Lawley, R.S.; Williams, C.N.; Anderson, M.G.; et al. Opinion: To advance sustainable stewardship, we must document not only biodiversity but geodiversity. Proc. Natl. Acad. Sci. USA 2019, 116, 16155-16158. [CrossRef]

99. Pereira, P.; Pereira, D. Methodological guidelines for geomorphosite assessment. Geomorphologie 2010, 16, 215-222. [CrossRef]

100. Kubalíková, L.; Kirchner, K. Geosite and Geomorphosite Assessment as a Tool for Geoconservation and Geotourism Purposes: A Case Study from Vizovická vrchovina Highland (Eastern Part of the Czech Republic). Geoheritage 2016, 8, 5-14. [CrossRef]

101. Brilha, J. Inventory and Quantitative Assessment of Geosites and Geodiversity Sites: A Review. Geoheritage 2016, 8, 119-134. [CrossRef]

102. Reynard, E.; Perret, A.; Bussard, J.; Grangier, L.; Martin, S. Integrated Approach for the Inventory and Management of Geomorphological Heritage at the Regional Scale. Geoheritage 2015, 8, 43-60. [CrossRef]

103. Kubalíková, L. Assessing Geotourism Resources on a Local Level: A Case Study from Southern Moravia (Czech Republic). Resources 2019, 8, 150. [CrossRef]

104. Selmi, L.; Coratza, P.; Gauci, R.; Soldati, M. Geoheritage as a Tool for Environmental Management: A Case Study in Northern Malta (Central Mediterranean Sea). Resources 2019, 8, 168. [CrossRef]

105. Pica, A.; Luberti, G.M.; Vergari, F.; Fredi, P.; Del Monte, M. Contribution for an urban geomorphoheritage assessment method: Proposal from three geomorphosites in Rome (Italy). Quaest. Geogr. 2017, 36(3), 21-36. [CrossRef]

106. Kubalíková, L.; Kirchner, K.; Kuda, F.; Bajer, A. Assessment of Urban Geotourism Resources: An Example of Two Geocultural Sites in Brno, Czech Republic. Geoheritage 2020, 12, 7. [CrossRef]

107. Carrión Mero, P.; Herrera Franco, G.; Briones, J.; Caldevilla, P.; Domínguez-Cuesta, M.J.; Berrezueta, E. Geotourism and Local Development Based on Geological and Mining Sites Utilization, Zaruma-Portovelo, Ecuador. Geosciences 2018, 8, 205. [CrossRef]

(C) 2020 by the author. Licensee MDPI, Basel, Switzerland. This article is an open access article distributed under the terms and conditions of the Creative Commons Attribution (CC BY) license (http://creativecommons.org/licenses/by/4.0/). 